\title{
Banal and Implied Forms of Violence in Levinas' Phenomenological Ethics
}

Fleurdeliz R. Altez

\author{
Your slain were not slain by the sword, \\ Your dead have not fallen in battle... \\ That is why I say, "Turn your eyes away from me, \\ Let me weep bitterly; \\ Do not try to comfort me \\ Over the destruction of the daughter of my people." - \\ Isaiah 22: 2,4, Jerusalem Bible
}

$\mathrm{D}$ espite his final call for peace and "the wisdom of love", Emmanuel Levinas inevitably spoke of violence, and perhaps spoke even more of it. His call for infinite responsibility is actually crystallized through discourse on violence and suffering. We may say that these themes served as catalysts to the standing theory and, ethically, to any responsible Self. Violence, at least as a concept, poses itself as a significant presence to Levinas' plantilla while it reaches unexplored dimensions that await phenomenology and vital thought. As a part of his ethical proposal, understanding violence becomes important so that the Self may go beyond it while reaching the Other. Proving this claim furthers me to raise three particular issues.

1) Violence was a part of the human condition when Levinas was brewing his intellectual project. The mind "grew" from 1920s to 60s which historically resulted in countless conflicts among societies and/or states coming from different political inclinations and offending persons and even races. He wrote,

... this is the century that in thirty years has known two world wars, the totalitarianisms of right and left, Hitlerism and Stalinism, Hiroshima, the Gulag, and the genocides of Auschwitz and Cambodia. This is the century that is drawing to a close in the obsessive fear of the return of everything these barbaric names stood for: suffering and evil inflicted deliberately, but in a manner no reason set limits to, in the exasperation of reason become political and attached from all ethics. ${ }^{1}$

${ }^{1}$ Emmanuel Levinas, "Useless Suffering", in Entre Nous Thinking of the Other, trans. by Michael B. Smith and Barbara Harshav (New York: Columbia University Press, 1998), 97. Henceforth EN. 
I hold that any thinker who has had a taste of this deserves to have his view on violence heard.

At this juncture, it is interesting to note that Levinas started his Totality and Infinity through a reflection on war. Succinct and vivid, he described war as a form of annihilation that destroys not just the Other, but also Sameness (i.e., the relation the Self builds with the Other), and even the subjectivity of the Self who wages it. He wrote, "...every war employs arms that turns against those who wield them."2 War, even if geared to victory and peace does not promise such, because anything that is annihilated or at least alienated can only be restored. ${ }^{3}$ Political and ethical redemption inasmuch as they are in human forms cannot bring man back to his primordial and original relation with being. Getting over a war is not a form of transcendence but of mere retrieval. War is a violent and permanent disruption of man making his own project. Levinas' sensitivity to violence - both in theory and human affairs - is brought by the over-all temperament of his (historical) dwelling, the experience of war and so the subjective taste of such disruptions.

2) Violence is at the center of the Levinasian critique. Levinas did not just talk about and criticize forms of violence; we may say that he (in a way) employed it, thus affirming it as a mechanism. The radicality of the Levinasian proposal rests on the radical nature of his critique of Western Philosophy. Violence, in this case, comes as a provision in the task of philosophizing. Emerging from the phenomenological training of Husserl and Heidegger, Levinas is definitely aware of the heavy ontological bearing of "thinking". Nonetheless, he recognizes that in order to see an ethical relation that goes beyond ontology, violence must be settled as a point of criticism and perhaps as a plausible reason for responsibility.

3) Other than being a focal point of critique, violence may still assume different places in this ethical plantilla - from the method, the critique, even down to the proposed resolution. To note, this sense of altruism does not necessarily authenticate responsibility to the Other, and moreso the good of the Other. In other words, violence can still be present even in the act of generosity. Proving this would be one of my main tasks here.

While responsibility is deemed as a noble task, the author through this paper intends to show that answering to and for the Other cannot take on a single route to goodness unless identified to an axiological source. Responsibility can still be a plausible dwelling of violence. And - as my way of being responsible for an ethical proposal that is so dear to postmodernity - this

\footnotetext{
2 Emmanuel Levinas, Totality and Infinity: an essay on exteriority, trans. by Alphonso Lingis, (Pennsylvania: Duquesne University Press, 2001), 21. Henceforth TI.

3 Annihilation and alienation take being to another path, disintegrating former plans, twisting well-thought of means of becoming authentic. In this juncture, Levinas is like telling us that war has its way of altering how man builds himself. Even if we are faced with the reality that any war can end, and that it aims for victory and peace -- what will be done could just be a part of troubleshooting. "The peace of empires issued from war rests on war. It does not restore to the alienated beings their lost identity." Ibid., 22.
} 


\section{BANAL AND IMPLIED FORMS OF VIOLENCE}

paper shall explore the varieties of violence within Levinas' three-fold articulation of being, from the pre-ontological to the ethical level.

The paper shall start with a discussion on how Levinas thinks of violence posing it as an attitude to epistemology, metaphysics and human affairs. This will go with a hermeneutic (a Levinasian treatment of Levinas) as we look for the presence of violence in his very method and ethical proposal. This portion then identifies the forms of violence, both evident and implied. After which, we will assess whether (and if so, how) these forms can be conquered through resolutions that are still amenable to the Levinasian framework.

\section{Emmanuel Levinas on Violence}

Levinas' common approach to violence is more descriptive than definitive. Nonetheless, his descriptions would always be basic yet vivid - they bear on affectivity, immediately appealing to the human condition although in some instances he speaking merely of a general intellectual attitude. ${ }^{4}$ The Levinasian discourse proceeds as a review of dispositions and responses to ideas and persons ${ }^{5}$, so that when he speaks of violence readers may confuse themselves for his referents, leading them to ask whether he speaks of violence as reduction or actual tyranny, an epistemic dissection or a real-bloody genocide.

Violence is viewed as a condition for totality and a negation of infinity. It absolutizes being through a cruel negation of its possibilities. Violence is a

4 We may attribute this to the phenomenological tradition where Levinas came from, and perhaps also to the post-structural attitude that his discourse had been provoking. An excerpt from his essay "Transcending Words" may be used as springboard for justification: "Philosophy and contemporary sociology have accustomed us to underestimating the direct social contract of people speaking, in order to favor silence or the complex relations determined by civilization and its categories, such as customs, law and culture. A scornful bias against words which is the result of the pitfalls intrinsic to language - its many faceted ability to turn into chatter and impediment." "Transcending Words: Concerning Word-erasing," in Yale French Studies, vol. 81 (1992), 148.

It is clear that Levinas, in upholding alterity, affirms the sustenance of life. Hermeneutically, this is rendered to a text through criticism and dialogue that appeals straight to persons, and more importantly to the Other. This means that ideas are not thought but exemplified. And so the best way of speaking it would be through actions - an encounter of the Self to the Other. Phenomenology as a method in arriving at "things", appeals to lived experience; post-struturalism on the other hand liberates the thinker from finitude of structures. Considering both would mean, honoring the vitality and open-endedness of human experience. We can only have a taste of being human, if we "live it" - yet our lives cannot be encapsulated, since our vitality provokes unexpected ruptures.

5 Readers of Levinas and his secondary literature ought to understand that his discourse is very hermeneutically-open, thus making them provisionally classifiable under Ontological (Rhetoric), Affective (Aesthetic and Ethical) and Transcendental (Religious). See Fleurdeliz Altez, "Exploring the Hermeneutic Possibilities of the Levinasian Text," Unitas, vol. 79, no. 3 (September 2006), 563-568. The Levinasian text mirrors the frailty and strength of the message being addressed. Cf. Colin Davis, Levinas: an introduction (Great Britain: University of Notre Dame Press and Colin Davis, 1996), 141. In a way, the text appeals to the Self as an Other - therefore making the reading process an attitude for hospitality and responsibility. 
dictatorial and stagnating situation that prevents the disruption of totality. It strikes right into being thereby depriving one of the freedom that one seeks to enjoy - it is an experience of terror that brings a free man under the domination of another. ${ }^{6}$ Ironically, it is a work of ontology that destroys ontology. It is a by-product of egoism, of an exercise of power that subordinates the Other to the relation with Being, coercing him to obey something anonymous and forcing him to succumb to tyranny. ${ }^{7}$

As a consequence, violence brings forth suffering which is taken not only as a form of passivity, but as a negation - a form of un-meaning. "The humanity of those who suffer is overwhelmed by the evil that rends it, otherwise than by non-freedom: violently and cruelly, more irremissibly than the negation that dominates or paralyzes the act in non-freedom."8 And for this, suffering is useless: it is meant for nothing. Suffering is diabolic insofar as it is the "impasse" of life and being - bearing an absurd pain as its affective outburst. When one suffers, there can be no retreat from its bearings while one is being robbed of his will and is threatened of death by another. In the Totality and Infinity we read:

The whole acuity of suffering lies in the impossibility of fleeing it, of being protected in oneself from oneself; it lies in being cut off from every living spring. And it is the impossibility of retreat. Here the only future negation of the will in fear, the imminence of what escapes power, is inserted into the present; here the other grasps me, the world affects, touches the will. In suffering reality acts on the in itself of the will, which turns despairingly into total submission to the will of the Other'. In suffering the will is defeated by sickness. ${ }^{10}$

In the essay Useless Suffering, it is mentioned that suffering brings forth pain. For Levinas, felt pain remains undiluted so that it either isolates or absorbs one, from or to consciousness. Pain brought by suffering and coming from violence becomes the central phenomenon of the diseased state. ${ }^{11}$ More than on the affective state of suffering and pain, Levinas flexed his discourse on the human experience in the midst of history. He notes:

... the bad and gratuitous meaningless of pain already shows beneath the reasonable forms espoused by the social 'uses' of suffering, which in any case do not

\footnotetext{
${ }^{6}$ Levinas, TI, 44.

${ }^{7}$ Ibid., 46-47.

${ }^{8}$ Levinas, "Useless Suffering," EN, 92.

9 I am proposing that this be understood under the context of the "offender" or "disturber".

${ }^{10}$ Levinas, TI, 238.

${ }^{11}$ Levinas, "Useless Suffering", EN, 93.
} 


\section{BANAL AND IMPLIED FORMS OF VIOLENCE}

diminish the outrage of the torture that strikes the physically handicapped, isolating them in their pain. But behind the rational administration of pain in the penalties meted out by human courts, which immediately begin to look suspiciously like repression, the arbitrariness and strange failure of justice amidst wars, crimes and the oppression of the weak by the strong, rejoin, in a sort of fatality... Beyond the fundamental malignity of suffering itself, revealed in its phenomenology, does not human experience in history attest to a wickedness and an ill will? ${ }^{12}$

By this, Levinas speculates that suffering is (obviously) unwanted. However, it is not sourced from conditions that are merely accidental. Despite the truism that nobody wants to suffer - that I do not intend to go through any painful experience - suffering is brought by another who is, more often than not, intentional or intending. For Levinas, suffering comes from an executioner - an arbiter of violence with whom we cannot find a Face. ${ }^{13}$ This executioner is taken as a murderer, a violator of the core commandment that every Face would speak - "Thou shall not kill." This merciless and faceless executioner in a way robs the Other's Face of his ethical significance, with the effacement ranging from the human to the interhuman. ${ }^{14}$ It is interesting to note, however, that Levinas admits an ethical dilemma in the treatment of an executioner. In an interview where he is asked whether an SS officer has a Face, Levinas replied, "a very troubling question that calls, to my mind, for an affirmative answer. An affirmative answer that is painful every time!"15

12 Ibid., 95.

${ }^{13}$ Emmanuel Levinas, "Philosophy, Justice and Love," in EN, 105.

14 To elaborate this point, we quote from Levinas, "To think suffering in an interhuman perspective does not amount to seeing it in the coexistence of a multiplicity of consciousness, or in a social determinism, accompanied by a simple knowledge that people in society can have of their proximity or of their common destiny. The interhuman perspective can subsist, but can also be lost, in the political order of the City where Law establishes mutual obligations between citizens... The interhuman is also in the recourse that people have to one another for help, before the astonishing alterity of the other has been banalized or dimmed down to a simple exchange of courtesies that has become established as an "interpersonal commerce" of customs." Levinas, "Useless Suffering", EN, 101.

15 See Emmanuel Levinas, "A quoi pensent les philosophes?," trans. by Peter Atterton, in Autrement 102 (1988), 53-60 which is Atterton's personal translation of an interview in 1987). This portion is Levinas' response to Jean Toussaint Desanti's query to a Japanese scholar who was writing on his ethics. Mediating the aforementioned statement with what Levinas said in "Philosophy, Justice and Love" (EN, 105) would mean viewing the executioner as somebody who no longer has a Face. Peter Atterton creatively described this as an "eclipse" brought by justice, hence bringing forth a perspective of violence that is not at all antagonistic [see Peter Atterton, "In Defense of Violence: Levinas and the Problem of Justice" in $<$ http://ghansel.free.fr/atterton.html\# edn12> (2 April 2007)]. At this juncture, we find out new ethical issues on the executioner's end. And the coming of these new questions can be taken as a hermeneutic invitation to see violence in a broader scope. 
Another consequence of violence would be the experience of weakness, which insinuates an affective experience of a lack. Being unable to conquer a cruel kind of dominance, it marks passivity, loss of words, dearth, exhaustion and eventually - frustration. Post-structuralist Maurice Blanchot also speaks of this in a very Levinasian tone:

Weakness is grief weeping without tears; it is the murmur of the plaintive voice of the restless rustling of that which speaks without words, the dearth, the exhaustion of appearance. Weakness eludes all violence, which, even if it is oppressive omnipotence, can do nothing to the passivity of dying. ${ }^{16}$

\section{Violence in Epistemology, Metaphysics, and Ethics}

In this portion, allow me to pick three main areas where violence has direct involvement to being (and so to philosophy at large): Epistemology which covers the thinking of being; Ontology which articulates (the meaning of) being, and Ethics which speaks of the encounter of being.

EPISTEMOLOGY. Levinas considers the "traditional thinking" of "thinking" as an event of thematization and seizure trapped in thoughts and exchanged through words. It flows from consciousness, an ego - and is expressed through signifiers. The epistemic act is a cognitive predation where the mind sets a condition for totality in accepting another being while contradicting its autonomy. ${ }^{17}$ In understanding the ethical nuances of this mental act, Levinas recommends the use of the word "grasp."

To grasp is to reduce all experiences and all that is reasonable to a totality - to the Self. By self-consciousness, the thinker tries to cover the world so that nothing is left outside of it. The acquisition of knowledge is an activity that clutches otherness. The term "grasp" is a metaphor that, Levinas strictly advises, should be taken in its most literal sense. ${ }^{18}$ To grasp can be considered tantamount to possession, the form in which the other becomes the same, by becoming mine. ${ }^{19}$

This is best seen in rhetoric that aims to solicit the Other's approval. For Levinas, rhetoric is a discursive consequence of traditional epistemology where the Self learns how to dominate at least in the realm of ideas. It happens when one involves the Other in a conversation while robbing him of his freedom. Like in a fast-track salestalk or perhaps a time-budgeted television commercial, rhetoric is a soliloquy of the Self - a one-man show where the Other is assigned as a fixed audience (sit back and relax - I'll take care of everything, you only have to agree), where he is expected to respond in a

16 Maurice Blanchot, The Writing of the Disaster, trans. by Ann Smock (USA: University of Nebraska Press, 1995), 20-21.

${ }^{17}$ Levinas, TI, 25.

18 Ibid., 76.

${ }^{19}$ Ibid., 46. 


\section{BANAL AND IMPLIED FORMS OF VIOLENCE}

manner that is most amenable to the speaker or advertiser. For Levinas, this stifling of the Other, even in the simplest communication of ideas, is an experience of violence not on an inertia, but on a supposedly incorruptible freedom. ${ }^{20}$

The experience of violence in traditional epistemology can be taken on two ends: the part of the knower (Self) and the part of the known (Other). When reduced into indifferent structures, from thinking to the exchange of thoughts, legacies are epistemologically killed. Again from Levinas:

Bound to the universality of an impersonal reason, it would suppress the otherness of the interlocutor (who is irrational insofar as he is other) and the otherness of the $I$ who is speaking (who in his ipseity, also distinguishes himself as other from the discourse in which he is engaging. A reason cannot be other for a reason . . .. Impersonal discourse is a necrological discourse. Man is reduced to the legacy of man, absorbed by a totality of the common patrimony. The power he exercised over his work while living (and not only through the mediation of his work) - the essentially cynical man is annulled. Man becomes - not, to be sure, a thing - but a dead soul. ${ }^{21}$

It is important to note though that the damages done by traditional epistemology do not totally dismiss the endpoint of thinking, which is the truth of being. This critique only tells us that epistemology cannot but end with cold abstractions. While reduction and absolutism is rejected, a philosopher who is open to ethical growth, ontological ruptures and transcendence does not reject sincere cognitive and (more so) ethical destinations. We do not think for thoughts, we think for being. "The understanding of being implies not just a theoretical attitude, but the whole of human behavior."22 Levinas instead gives us a revised view of thinking by seeing it as an encounter of the Other in proximity. The Other is somebody exterior to being that must be understood while remaining exterior. This means to say that thinking cannot be a mere absorption and discourse can never be reduced to forceful feeding. In order for responsibility to take effect, the Other must remain safe from the violent grasp - thus, should only come through his own epiphany. At this point, we defy the language of rhetoric by entering into a relation of respect, where we allow thought to proceed to its surplus, by way of recognizing real and inviolable presence. ${ }^{23}$ And here we find the real value of speech. "The

${ }^{20}$ Ibid., 71.

${ }^{21}$ Levinas, "The I and the Totality," EN, 25.

${ }^{22}$ Levinas, "Is Ontology Fundamental?," Ibid., 2.

${ }^{23}$ Levinas, TI, 181. A complimentary note on the same opus would be this: "To have meaning is to be situated relative to an absolute, that is to come from that alterity that is not absorbed in its being perceived. Such an alterity is possible only as a miraculous abundance, an 
signifier must present himself before every sign, by himself - present a face."24 From the ideas, essence, and sense utility that we grasp - we come to understand beings of flesh and feelings. We encounter real faces and more not by forcibly sucking what's beneath, but by affirming the infinity beneath the physiological façade. Discourse comes through speech, but speech is meant not just as an exchange of thoughtful words but as an authentic human experience. From Levinas we quote:

Speech taken as an activity signifies as do furnishings or implements. It does not have the total transparence of the gaze directed upon the gaze, the absolute frankness of the face to face proffered at the bottom of all speech. ${ }^{25}$

Getting over epistemological violence is possible if thinking is progressive enough to set a language that can connect epistemology to ontology - hence, from thinking to being.

ONTOLOGY. The Levinasian dethronement of ontology as First Philosophy reveals varied manifestations of violence. As juxtaposed to traditional epistemology, (fundamental) ontology speaks of thematization in more blatant and concrete situations. This ontology voices out the Western will for power. "For 'I think' comes down to 'I can."'26 For Levinas, this ontology can never be First Philosophy since it potentially leads people to a despotic realm. As the philosophy of being, ontology also takes on as a philosophy of power and injustice with the unassailable freedom of the Self taking charge. ${ }^{27}$ As a consequence, the thematizing Self tyrannically converts the Other into the Same thereby resulting in impersonal fecundity. This ontology voices out the Western will for power. As the main thrust of the occidental intellectual tradition, it is indubitably the mindset that has spurred leaders and thinkers to declare wars, conquer nations and resources - to violate and even annihilate the Other.

The Levinasian ontology and the eventual realization of traditional egology proceed under his so-called three-fold articulation of being, and so we find out forms of violence under the same pattern:

a) In the IL YA through the horror and terror of anonymity. Violence comes through an existential void caused either by ontological deprivation or suspension. Through the il $y$, there is a cruel experience of "there is" while confronting the seeming moment that there's none. The disgust in this stage of non-/pre-identification is a form of suffering, and the means by which one experiences it is a form

inexhaustible surplus of attention arising in the ever recommenced effort of language to clarify its own manifestation." Ibid., 97.

${ }^{24}$ Ibid., 182.

${ }^{25}$ Levinas, "Is Ontology Fundamental?," loc. cit.

26 Op. cit., 46.

${ }^{27}$ Ibid., 47. 
of violence. The paradoxical character of the il y a makes it a horrible and disgusting experience. ${ }^{28}$ It brings not anguish, but horror. As Levinas said, it is the horror of unceasing, a monotony deprived of meaning. It is a horrible and useless insomnia. ${ }^{29}$ A moment of being awake while one wants to be asleep, or even reversed - in times when the spirit is willing but the flesh is just weak. It is hearing the monotony of silence in the night. The terror is brought by one's dread that its impersonal character might lead to an absolute loss of selfhood. Fr. Adriaan Peperzak noted that the immersion in the abysmal chaos of there is would be tantamount to the absorption of a depersonalizing realm of pure materiality - a state that being would always desire to elate ${ }^{30}$ Dwelling here shows one's incapability of coming into a hypostatic moment, and so one's weakness and failure to conquer a dominant source of suffering because it is practically unknown. In the ily $a$, the straightforward enemy is silence. ${ }^{31}$

b) In HYPOSTASIS through the ontological ruptures of the Self. This stage means to break free from the state of anonymity. The impersonal paradox brought by the il $y$ a is only conquered when

${ }^{28} \mathrm{Il} y \mathrm{y}$ is an impersonal paradox. Levinas, in his description of this concept defied traditional logic because il $y$ a is the excluded middle: "One cannot say of this 'there is' which persist that it is an event of being. One can neither say that it is nothingness, even though there is nothing." See Ethics and Infinity (Conversations with Philippe Nemo), trans. by Richard A. Cohen (Quezon City: Claretian Publications, 1997), 48. To Levinas, the Il $y$ a is a phase without any phase. It is particularly indeterminate and shapeless - yet, there is something. To Levinas, this brings the feeling of rustling and rumbling, as how a child feels when tucked to his bed early while hearing the adults continue their lives outside. It is like what is heard inside an empty seashell when it is put close to the ear - it is empty and there is silence, but a certain noise persist. "In the absolute emptiness that one can imagine before creation - there is." Levinas in an interview with Francois Poirie, Is it Righteous to be? Interviews with Emmanuel Levinas, ed. by Jill Robbins (California: Stanford University Press, 2001), 48. Henceforth IRTB.

29 Ibid., 45.

30 Adriaan Peperzak, To the Other: an introduction to the philosophy of Emmanuel Levinas (West Lafayette, Ind.: Purdue University Press, 1993), 18.

31 “. . . silence is not a simple absence of speech; speech lies in the depths of silence like a laughter perfidiously held back. It is the inverse of language: the interlocutor has given a sign, but has declined every interpretation; to the assistance of the sign given forth, attending his own manifestation in signs, redressing the equivocal by his attendance.

The evil genius' lie is not an utterance opposed to the veridical word; it is in that interspace between the illusory and the serious in which a subject who doubts breathes. The evil genius' lie is beyond every lie; in the ordinary lie the speaker dissimulates himself, to be sure, but in the dissimulating word does not evade speech and hence can be refute. The inverse of language is like a laughter that seeks to destroy language, a laughter infinitely reverberated where mystification interlocks in mystification without ever resting on a real speech, without ever commencing. The spectacle of the silent world of facts is bewitched: every phenomenon masks, mystifies ad infinitum, making actuality possible .... A world absolutely silent, indifferent to the word never uttered, silent in a silences that does not permit the divining, behind the appearances, of anyone that signals this world and signals himself by signaling this word -be it to lie through appearances, as an evil genius - a world so silent could not present itself as spectacle." TI, 91-92, 94. 


\section{F. ALTEZ 61}

Being is finally enlightened. Hypostasis then means, for Levinas, the integration or affirmation of the Self as the principle of identity, which shall empower the "I". The proposal of this stage implicitly confirms the imperious presence of ontology in ethical affairs. As the first emergence of the self, hypostasis is the eruption of being and starts with the recognition of things one can take into the self for the purpose of life and self-sufficiency. It suggests a necessary egoism that Levinas prescribes for the Self not to plunge into, because even if it necessarily leads to the intersubjective the violent situation between the Self and the Other treated as the Same can be realized here. ${ }^{32}$ Moreover this first experience of identity calls for an opening and veritable departure where he finds himself insufficient when left on his own. "The human will pass by another decisive stage in which the subject, despite its satisfaction, fails to suffice unto itself." True enough, every act is a way of going beyond one's stability - a more radical surplus of being. ${ }^{33}$ In coming to another ontological level, he finds the Face. ${ }^{34}$

c) In the ENCOUNTER OF THE FACE through murder. The Face is capable of expressing primordial signs due to its very uprightness. It is bare, therefore visible and exposed - nude. ${ }^{35}$ The Face of the Other, however, can also be hidden by a mask. The Other might try to conceal the real expression on his face, but "the act of facing itself is actually unmasking." 36 The face's unsuccessful attempts to hide bring forth two opposing, but complementary notions: frailty and demand. Levinas explains frailty by describing it as an extreme form of weakness. However, this feebleness gives the Other either or both of these impressions: the fragile face as easily susceptible to destitution

32 For this Levinas, hypostasis only serves as a bridge that may actualize the person as true ethical individuals. Hypostasis, as an ethical event serves as the "kernel", the main conceptual seed of what Levinas would be proposing afterwards. IRTB, 45-46.

33 "What, in action, breaks forth as essential violence is the surplus of being over the thought that claims to contain it, the marvel of the idea of infinity." TI, 27.

34 A face identifies a being. Through the face, being manifests "himself to himself". The face, in fact, is already meaning all by itself. In this manner the face is already "unseen". Vision, according to Levinas, is only a search for adequation — it is only what best absorbs being, but does not really explains what a being is. For him, it is the fundamental event - it is the most special among the modalities by which being enters into a social relationship.

35 To support, we quote from Levinas: "The things are naked, by metaphor, only when they are without adornments: bare walls, naked landscapes. They have no need of adornment when they are absorbed in the accomplishment of the function for which they are made: when they are subordinated to their own finality so radically that they disappear in it. They disappear beneath their form. The perception of individual things is the fact that they are not entirely absorbed in their form; they then stand out in themselves, breaking through, rending their forms, are not resolved into the relations that link them up to the totality." TI, 74.

36 Virginia L. Jayme, "Emmanuel Levinas' Philosophy of Responsible Subjectivity," in Philippiniana Sacra, vol. XXVI no. 77 (1991), 245. 


\section{BANAL AND IMPLIED FORMS OF VIOLENCE}

or/and afterwards the demands of the face in its weakest and poorest manifestation.

When there is nakedness in the face, there is also destitution. This now shows how vulnerable the face of the Other is. And through this vulnerability, the Self may be induced to take advantage, inviting the Self to an act of violence. The weak disclosure of the face makes it susceptible to the Self's utility. But worse than totalization is the threat of annihilation, hence violence in its blatant form. As Levinas said, "One can kill, annihilate. It is easier to annihilate than to possess the other." 37 More from Levinas:

True self-expression stresses the nakedness and defenseless that encourages and directs the violence of the first crime ... the goal of a murderous uprightness is especially well-suited to exposing or expressing the face. The first murderer probably does not realize the result of the blow he is about to deliver, but his violent design helps him to find the line with which death may give an air of unimpeachable rectitude to the face of the neighbour; the line is traced like the trajectory of the blow that is dealt and the arrow that kills. ${ }^{38}$

Levinas affectively heightens this by talking about murder. This act aims at a sense datum while finding itself in front of a non-neutralizable object. As total negation, murder does not only dominate but destroy. "Murder exercises a power over what escapes power. It is still a power, for the face expresses itself in the sensible, but already impotency, because the face rends the sensible." 39 As the most banal incident of human history and the total negation of a being, murder does not care about the force that the Other may possess as part of the world. The Other who can freely refuse is immediately exposed to the murderer - "the point of the sword or the revolver's bullet" - it threatens his stability since this sword or bullet had already touched the ventricles of his heart. ${ }^{40}$ And for murder on the larger scale, where else would Levinas direct his readers but to his emotionally-driven description of the Nazi genocide?

Whole peoples have been killed for "rational" (however horrifying) ends such as power, territory, wealth ... The Nazi murder . . . was annihilation for the sake of

\footnotetext{
${ }^{37}$ Levinas, "The Paradox of Morality," in The Provocation of Levinas: rethinking the Other, ed. by Robert Bernasconi and David C. Wood (London: Routledge, 1998) 170. Henceforth TPOLRTO.

${ }^{38}$ Levinas, "Ethics as First Philosophy," The Levinas Reader, ed. by Sean Hand (Oxford, UK: Blackwell Publishers, 1989), 83.

39 TI, 198.

${ }^{40}$ Ibid., 199.
} 
annihilation, murder for the sake of murder, evil for the sake of evil. Still more incontestably unique that the crime itself is the situation of the victims. The Albigensians died for their faith, believing unto death that God needs martyrs. Negro Christians have been murdered for their race, able to find comfort in a faith not at issue. The more than one million Jewish children murdered in the Nazi holocaust died neither because of their faith, nor despite their faith, nor for reasons unrelated to the Jewish faith [but] because of the Jewish faith of their great-grandparents [who brought up Jewish children]. ${ }^{41}$

\section{Violence in Ethics: On Generosity and Justice}

The Face phenomenologically reveals the Other, beyond which epiphany is taking into one's heart a sense of responsibility. As the highest criterion of ethics, there exists the face demanding for a response. And consequently, the ability to respond is the meaning of the term Responsibility (i.e., response-ability). For Levinas, the Self's reply to the face is not just a response but a responsibility, as these two words (résponse and responsibilité) are related. ${ }^{42}$

This is made possible by the vulnerability of the nude face. Its nakedness eludes the Self, it seemingly pushes me to desire for its voluptuousness which is actually too sublime for me to consume. Levinas calls this longing as the metaphysical desire which fails to gratify man, yet compels him into performing a concrete ethical resolve. For this Levinas says that the metaphysical desire, though perpetually ungratified, shall lead to generosity or goodness and discourse. ${ }^{43}$ The Self gets to see, on the other side of the Face,

${ }^{41}$ Levinas, "Useless Suffering", EN, 65.

42 Levinas, "Paradox of Morality, TPOLRTO, 169. I think that Levinas seemingly alludes a notion of Gabriel Marcel who said that responsibility is the human person's ability to respond.

${ }^{43}$ Levinas speaks of this metaphysical desire at the beginning of the Totality and Infinity where he notes how it indicates the ontological insufficiency of the Self, who tends to look for something more in order to achieve self-authentication. He writes: "The metaphysical desire tends toward something else entirely, toward the absolutely other. The customary analysis of desire can not explain away its singular pretension. As commonly interpreted need would be at the basis of desire would characterize a being indigent and incomplete or fallen from its past grandeur. It would coincide with the consciousness of what has been lost; it would be essentially a nostalgia, a longing for return. But thus it would not even suspect what the veritably other is.

The metaphysical desire does not long to return, for it is desire for a land not of our birth, for a land foreign to every nature, which has not been our fatherland and to which we shall never betake ourselves. The metaphysical desire does not rest upon any prior kinship. It is a desire that can not be satisfied. For we speak lightly of desires satisfied, or of sexual needs, or even of moral and religious needs. Love itself is thus taken to be satisfaction of a sublime hunger. If this language is possible it is because most of our desires and love too are not pure. The desire can resemble metaphysical desire only in the deceptions of satisfaction or in the 


\section{BANAL AND IMPLIED FORMS OF VIOLENCE}

what could be behind the voluptuous and the mysterious. And so, as the Self sees the vulnerability of the Other's nude face, he is now being summoned to look after the Other. The Other's face, the fact that he/she looks at me, makes me a servant. To see the desolate face which cries out for justice is to put oneself as responsible to the being which presents itself in the face. Ergo, "responsibility for the Other operates in the field of gravity of the Other's demand." 44

A responsibility for my neighbor, for the other man, for the stranger or sojourner, to which nothing in the rigorously ontological order binds me, nothing in the order of the thing, of the something, of number or causality. ${ }^{45}$

Responsibility is initially for the Other, and such a responsibility of the Self cannot be transferred. Responsibility is incumbent on the Self exclusively, that which can never be refused. No one can replace the Self in fulfilling his obligations to the Other. "I can substitute myself for everyone, but no one can substitute himself for me." 46

Given this, where is violence in the act of generosity and responsibility?

Despite the "inevitable" responsibility of the Self to the Other, the Self is never sure if the Other is in turn responsible for him. This is due to the assymetrical relationship these two entities have. Levinas now states that in this sense the Self has no business waiting for reciprocity of his actions from the other. Reciprocity greatly depends on the Other. ${ }^{47}$ This means that the Self, in doing his obligation, has to be selfless - he has to do it without waiting for reciprocity, even if he has to die for it. As Levinas is always fond of quoting, "We are all responsible for all men before all, and I more than all the others ..." I remember Dr. Hornedo in one of his casual lectures at the UST Graduate School saying that the Levinasian call of being responsible without the promise of a return is like signing a blank cheque where I am willing to give anything for the Other, by all means and at all costs. But this cannot be done blindly.

The face-to-face encounter, however, does not signify that only two persons can be involved. While there is the Autrui, there can also be the autre.

exasperation of non-satisfaction and desire which constitutes voluptuousity itself. It is like goodness - the Desired does not fulfill it but deepens it." TI, 33-34. Levinas expands his discourse on the metaphysical desire at the latter part of this same work, particularly at the section "Phenomenology of Eros" which embodies his notion of love. See Ibid., 256-266.

44 Bernhard Waldenfels, "Response and Responsibility in Levinas," Ethics as First Philosophy The Significance of Emmanuel Levinas for Philosophy, Literature and Religion, ed. by Adriaan T. Peperzak (New York: 1995), 47.

45 Levinas, "Ethics as First Philosophy," 84.

${ }^{46}$ Levinas, Ethics and Infinity, 101. Levinas alludes to his notion of substitution, which will be discussed at the latter portion of this chapter.

${ }^{47}$ Ibid., 98. 
The autri refers to the personal Other, while the autre refers to the otherness in general.48 Aside from the Self and the Other, other faces may be involved, thus making up the third party (that is, of the whole humanity which looks at us). Just like the Other, the Self is also responsible to the third party. After all, every human that man encounters is the Other that we personally treat, and such if collectively taken yields what is called the Other in general, the other Others.

Responsibility therefore is not only for a single Other, but for every Other that exists. This also calls the self not only for a personal encounter, but for a relationship that may extend to a larger community. Through the multiplicity of the existence of the other, Levinas now brings into surface his notion of justice.

In Totality and Infinity, Levinas spoke of justice as bound to social relation. One of his descriptions of justice is, "the recognition of (his) privilege qua Other (and his mastery)... and coincides with the overcoming of rhetoric", which he describes as ruse, emprise and a form of exploitation 49 The recognition of the existence of many "others" entails that responsibility is not limited to a single other. Consequently, the Self who is confronted by many others now commits himself to respond to the needs of these others. However, these needs are varied and contradicting — as there might even exist needs that may be benefiting some, but detrimental to others. "Justice is the way in which I respond to the face that I am not alone in the world with the (single) other." ${ }^{50}$

I think that Levinas allowed some clues in solving this problem when he said that, "if there were no order of Justice, there would be no limit to my responsibility." 51 Due to the existence of another Other, responsibility also means the Self's consciousness and ability to assess which among these responsibilities should be limited and exercised. Beyond the face to face is a world of citizens, a greater number of Others. Consequently, this implies the necessity to having institutions and states, who will be the arbiters in every Self's ethical endeavors that are directed to a larger scale. However, one must be cautious because violence may be (and, for sometimes, is inevitably) used in the exercise of justice. Levinas himself admits the existence of violence in the fulfillment of justice in his ethical thought. As he confirms,

There is an element of violence in the state, but the violence can involve justice. That does not mean violence must not be avoided as much as possible; everything that replaces it in the life between states, everything that can be left to negotiation, to speech, is

\footnotetext{
48 Ibid., Translator's note.

${ }^{49}$ Levinas, TI, 72.

${ }^{50}$ Levinas, "The Paradox of Morality", TPOLRTO, 174.

${ }^{51}$ Levinas, "Philosophy, Justice and Love", EN, 105.
} 
absolutely essential; but one cannot say that there is no legitimate violence. 52

This is a seeming contradiction to the Levinasian appeal for nonviolence as taken from the Judaeo-Christian commandment: Thou shall not kill. Nevertheless, the indispensability of violence in the exercise of justice (and all the polemics behind this notion), does not mean that its exercise must not be avoided. Levinas also mentions that as the responsible I must also find ways to allay the violent judgment. As Levinas says, "When the verdict of justice is pronounced, there remains for the unique I that I am the possibility of finding more to soften the verdict. There is a place of charity for justice." ${ }_{53}$

\section{Conclusion: A Provocation for an Axiology in Love, a Vocation to Worth and Goodness}

The varieties of violence within the Levinasian framework indeed range from the banal to the implied. Banal are those which are revealed outright - forms of violence that begin in thought and inflict the human person. Be it intended or otherwise, a mechanism or a vengeful infliction, the banality of violence is seen as a mere mechanism or a situation that is foreplay to negation and destruction. Going through the intricacies of the same framework plunges one to the forms of implied violence. On the one hand, under the guise of justice, violence slithers in the ethical system inasmuch as the responsible Self is confronted by a third party who compels him to limit his supposed infinite commitment to the Autrui. The absence of justice, on the other hand, threatens the Self with falling short of his responsibility. Unjustified generosity, probably brought by the indifferent gaze of the Face of the Other, could just lead to short-term aid, and perhaps even useless effort. ${ }^{54}$ Implied forms of violence then are still situations, some of which are inevitable mechanisms; nonetheless, unlike the banal forms, they are consequences that necessarily proceed from the ethical encounter. But just like the banal, implied forms of violence are meant to be conquered.

Postmodern predicaments like individuality in the midst of globalization and plurality in discourse are the factors that seemingly go against the purist view of Levinasian responsibility. They ironically stress infinity in terms of exercise, yet insinuate ethical (virtuous) anarchy when politically assessed. This also means that as long as Levinas intends to maintain the

52 Ibid., 106.

53 Op. cit., 175.

${ }^{54}$ Postmodern commentator Zygmunt Bauman saw these problems as he reflects upon the postmodern milieu, which is seemingly inhospitable to the philosophy of Levinas. In one of his essays, he placed postmodern view of justice which he described as an ethical movement from the micro to the macro level vis-à-vis the ethics Levinas that is ideally limited to two entities (the Self and Other/Autrui). Ethical problems emerge because of Levinas' shortsightedness to look into the expanded human capacities that in turn possess greater consequences." Zygmunt Bauman, "Morality begins at home: or the rocky road to Justice," in Postmodernity and its Discontents (New York: New York University Press,1997), 53-54. 
intimacy of an ethical encounter, the autré (third party) can never be accommodated without the violence that justice would impute, for the coming of the third party as Levinas himself mentions is the beginning of the proximity of human plurality where intentionality and representation necessarily come into picture. ${ }^{55}$ Levinas mentions this in an interview:

There lies a new difficulty, which invites us to a new development. We are not a pair, alone in the world, but at least three. Two plus a third. If I heed the second person to the end, if I accede absolutely to his request, I risk, by this very fact, doing a disservice to the third one, who is also my other. But I listen to the third, I run the risk of wronging the second one." 56

In this fragmented world where justice in human relationships (whose main interlocutors are the State and its laws) is impossible, the intimacy suggested by the personalism of Levinas brings nausea to the postmodern. Limiting human relations into the micro (one-on-one) level is utterly impossible for in this age, the community (the third party) bears so much weight and interlocutors for their welfare must exist. Moral relationships are bound to suffer in the antagonistic presence of justice.

If taken under the Levinasian light, justice takes on a violent reputation. Perhaps the way to solve this is to take justice as more than just a yearned state or a fixed virtue but as a dynamic process. Justice is never satisfied with itself and therefore a constant revision thereof will always be an expectation towards a better one. ${ }^{57}$ However, this justification still falls short of solving the threat of justice in an authentic relationship and in the personalism proposed by Levinas.

The road to goodness is indeed a rough one. A responsible encounter with an Other demands not just for a simple recognition of alterity and response to his/her needs. It also means being mindful of the act of responsibility. The problem of justice (the inevitable presence of violence) seems to call us to take responsibility as a "thoughtful generosity." Response is a by-product of being held-hostage, but I daresay that the Self still takes the command on how to witness the Other within proximity.

55 Levinas, "Diachrony and Representation," in Time and the Other (and addditional essays), trans. by Richard A. Cohen (Pittsburgh, Pennsylvania: Duquesne University Press, 2000), 106.

${ }^{56}$ Levinas, "In the Name of the Other", in IIRTB, 193.

57 While noting this endless clamor for better forms of justice, Bauman finally mentioned Richard Rorty who proposed an ethics based on campaign politics. Such is a descent towards the movement politics which is a matrix towards an "ideal" or the immediate solution of an issue. Exercise of justice would be more feasible in campaign politics that is bent towards the pragmatic than the transcendental, as in this situation one asks, What are the causal conditions of replacing this present actuality with a better future actuality? For this fragmented world, the postmodern individual who experiences fragmented events, what is needed is a fragmented politics. See Bauman, op. cit., 68. 


\section{BANAL AND IMPLIED FORMS OF VIOLENCE}

Another good anchor would be love. After all, it is love that waters down the violence of justice. While not being a usual Judaeo-Christian patch to its preferential loopholes and spoiling tendencies, Levinas takes on a unique stance while speaking of it as a "wisdom of nations." He demands for an increase of "sociality in love" - to find human peace and proximity more than the simple unity of the diverse. Levinas had always believed that a synthesis is possible in relationships such that the Self wages with Other[s] and at the same time recognize the uniqueness of each. ${ }^{58}$ To elaborate:

It is the moment of justice. The love of one's fellowman, and his original right, as unique and incomparable, for which I am answerable, tend of their own accord to make appeal to Reason capable of comparing incomparables, a wisdom of love. A measure superimposes itself on the "extravagant" generosity of the "for the other" on its infinity. Here, the right of the unique, the original right of man, calls for judgment and hence, objectivity, objectification, thematization, synthesis. It takes institutions to arbitrate and a political authority to support all this. Justice requires establishes the state. There is, to be sure, the indispensable reduction of human uniqueness to the particularity of an individual of a human genus, to the condition of the citizen. A derivation. But still its imperative motivation is inscribed in the very right of the other man, unique and incomparable.

But justice itself cannot make us forget the origin of the right or the uniqueness of the other, henceforth covered over by the particularity and generality of the human... It awaits the voices that will recall, to the judgments of the judges and statesmen, the human face dissimulated beneath the identities of citizens. Perhaps these are "prophetic voices."

An anachronism that may bring a smile to the lips! But prophetic voices probably mean the possibility of unforeseen acts of kindness of which the $I$ is still capable in its uniqueness preceding all genus or freed from all genera... in which freedom of expression is ranked as the first freedom and justice is always a revision fo justice and the expectation of a better justice. ${ }^{59}$

Regardless of violence, and in whichever form it comes as a threat, love ensures that the Levinasian paradigm can truly respond to its call to

\footnotetext{
${ }^{58}$ Levinas, "Uniqueness”, EN, 195-196.

${ }^{59} \mathrm{Ibid}$.
} 
altruistic servitude. Nonetheless, I daresay that the work of love, despite its having its own exclusive logic, is not at all stupid. And for this, we go back to sensibility - a thoughtful and sincere one. Sensibility reveals worth - it evokes the response that is governed by the Other as thoughfully witnessed by the Self. Another discourse on love would entail a longer paper; it is (perhaps) the most complex and grueling of all human relations. But to end this paper with an axiological anchor through thoughtful sensibility, allow me to quote Levinas:

Goodness, a childish virtue; but already charity and mercy and responsibility for the other, and already the possibility of sacrifice in which the humanity of man bursts forth, disrupting the general economy of the real and standing in sharp contrast with the perseverance of entities persisting in their being; for a condition in which the other comes before oneself. Dis-interest-estedness of goodness: the other in this demand which is an order, the other as face, the other who "regards me" even when he doesn't have anything to do with me, the other as fellow man and always stranger - goodness as transcendence; and I, the one who is held to respond, the irreplaceable, and thus the chosen and thus truly unique. Goodness for the first one who happens to come along, a right of man. A right of other man above all. ${ }^{60}$

Perhaps the key here is to truly think within oneself, for the Other and just for the Other.

Faculty of Arts and Letters, University of Santo Tomas, Philippines

\section{References}

Altez, Fleurdeliz, "Exploring the Hermeneutic Possibilities of the Levinasian Text," in Unitas, vol. 79 no. 3 (September 2006), 549-568.

Atterton, Peter, "In Defense of Violence: Levinas and the Problem of Justice," in < http://ghansel.free.fr/atterton.html\# edn12> (2 April 2007).

Bauman, Zygmunt, Postmodernity and its Discontents (New York: New York University Press, 1997).

Bernhard Waldenfels, Bernhard, Ethics as First Philosophy The Significance of Emmanuel Levinas for Philosophy, Literature and Religion, ed. by Adriaan T. Peperzak (New York: 1995).

Blanchot, Maurice, The Writing of the Disaster, trans. by Ann Smock (USA: University of Nebraska Press, 1995).

${ }^{60}$ Levinas, “The Rights of Man and Good Will”, EN, 158. 


\section{BANAL AND IMPLIED FORMS OF VIOLENCE}

Colin, Davis, Levinas: an introduction (Great Britain: University of Notre Dame Press and Colin Davis, 1996).

Jayme, Virginia L., "Emmanuel Levinas' Philosophy of Responsible Subjectivity," in Philippiniana Sacra, vol. XXVI no. 77 (1991), 227-262.

Levinas, Emmanuel, Entre Nous Thinking of the Other, trans. by Michael B. Smith and Barbara Harshav (New York: Columbia University Press, 1998). , Ethics and Infinity (Conversations with Philippe Nemo), trans. by Richard A. Cohen (Quezon City: Claretian Publications, 1997).

, Is it Righteous to be? Interviews with Emmanuel Levinas, ed. by Jill Robbins (California: Stanford University Press, 2001).

The Levinas Reader, ed. by Sean Hand (Oxford, UK: Blackwell Publishers, 1989).

The Provocation of Levinas: rethinking the Other, ed. by Robert Bernasconi and David C. Wood (London: Routledge, 1998). Time and the Other (and addditional essays), trans. by Richard A. Cohen (Pittsburgh, Pennsylvania: Duquesne University Press, 2000). , Totality and Infinity: an essay on exteriority, trans. by Alphonso Lingis (Pennsylvania: Duquesne University Press, 2001).

, "Transcending Words: Concerning Word-erasing," in Yale French Studies, vol. 81 (1992), 145-150.

Peperzak, Adriaan, To the Other: an introduction to the philosophy of Emmanuel Levinas (West Lafayette, Ind.: Purdue University Press, 1993). 